\title{
Transgenesis in Animal Agriculture: Addressing Animal Health and Welfare Concerns
}

\author{
Michael Greger
}

Accepted: 10 May 2010/Published online: 30 May 2010

(C) The Author(s) 2010. This article is published with open access at Springerlink.com

\begin{abstract}
The US Food and Drug Administration's final Guidance for Industry on the regulation of transgenesis in animal agriculture has paved the way for the commercialization of genetically engineered (GE) farm animals. The productionrelated diseases associated with extant breeding technologies are reviewed, as well as the predictable welfare consequences of continued emphasis on prolificacy at the potential expense of physical fitness. Areas in which biotechnology could be used to improve the welfare of animals while maintaining profitability are explored along with regulatory schema to improve agency integration in GE animal oversight.
\end{abstract}

Keywords Transgenesis - Biotechnology · Bioethics · Welfare · Production diseases

\section{Introduction}

The 2009 release of the US Food and Drug Administration's (FDA) industry recommendations for the regulation of genetically engineered (GE) animals in agriculture has generated further debate about the ethical implications of this nascent technology (Greger 2010). Critiques that have concentrated on unintended welfare effects, such as congenital abnormalities or perinatal mortality (Weaver and Morris 2005), have tended to ignore the consequences of the intended outcome of improved production efficiency. Selective farm animal breeding has historically been undertaken for purposes of economic advantage, even when at the expense of animal welfare, and research remains geared towards profitability (Thompson 2008). Genetic engineering will not necessarily diminish the welfare of animals in

M. Greger $(\square)$

Public Health and Animal Agriculture, Humane Society of the United States,

2100 L St., N.W, Washington, DC 20037, USA

e-mail: mhg1@cornell.edu 
agriculture, but given suffering associated with the epizootics of production diseases linked to traditional methods of genetic selection, there is legitimate reason for concern.

\section{Production-Related Disease Linked to Extant Breeding Technologies}

An in-depth look at the current problems associated with existing breeding priorities is first necessary to place the concerns and prospects of farm animal transgenesis in perspective. Decades of selecting traits for maximizing yield has led to endemic levels of so-called production diseases in all the major commercial farm animal species. With the emphasis now on productivity above all else, Rollin (2009) notes that after thousands of years of animal husbandry viewing disease as the enemy, it can now be seen as "an ally in the quest for profit." Production disease, as defined in one early dialogue, "is a [hu]man-made problem; it consists of a breakdown of the various metabolic systems of the body under the combined strain of high production and modern intensive husbandry" (Payne 1972).

\section{Dystocia in Double-Muscled Beef Cattle}

Since the early 1980s when Palmiter et al. $(1982,1983)$ demonstrated that one could nearly double the weight of mice through the integration and expression of rat or human growth hormones, the livestock industries have reportedly expressed keen interest in utilizing this technology (Westhusin 1997). Double-muscling is an inborn genetic defect maintained in certain breeds of cattle caused by a "natural knockout" of a muscle protein gene, resulting in under regulated muscular growth (McPherron and Lee 1997). The extreme muscularity makes caesarean section a "necessary breeding technique" due to severe feto-maternal disproportion (Uystepruyst et al. 2002). Calves are also at risk for macroglossia (enlarged tongue), due to hypoglossal hypertrophy, which may result in an inability to suckle, and congenital articular rigidity (frozen joints), thought due to insufficient intrauterine freedom of movement, which may result in an inability to stand; both conditions may require euthanasia (Lips et al. 2001).

These problems inherent to double-muscling have led certain European countries to consider banning the intentional breeding of such cattle on animal welfare grounds (Lips et al. 2001), but the creation of the "mighty mouse" (Rodgers and Garikipati 2008), with up to triple the muscle mass (McPherron et al. 1997), has reignited expectations within the agribusiness community that this mutation could successfully be transferred to sheep, pigs, chickens, turkeys, and fish (McPherron and Lee 1997).

Most fish are oviparous, so would avoid the perinatal problems suffered by their mammalian counterparts. Early attempts to manipulate muscle gene expression in commercial fish species has produced a distinct "six-pack" pattern of double muscling in trout (Medeiros et al. 2009), but in medaka led to irregular muscle fiber misalignment abnormalities while failing to grossly increase muscle mass (Sawatari et al. 2010). Options for circumventing calving difficulties in mammalian livestock 
include a conditional gene targeting approach that allows for postnatal gene disruption restricted to later stages of development (Laible 2009).

\section{Lameness, Metabolic Disorders, and Mastitis in Dairy Cattle}

Based on locomotion scoring studies of more than 9,000 dairy cows in Wisconsin (Cook 2003) and Minnesota (Espejo et al. 2006), two top US dairy-producing states (US Department of Agriculture (USDA) 2008a), the prevalence of clinical lameness among US dairy cattle may be as high as $24.6 \%$ (Espejo et al. 2006). Lameness has been found to be the factor most associated with increased dairy cow mortality in the United States in a multivariate analysis of risk (McConnel et al. 2008). Although concrete flooring, insufficient physical activity, and lack of access to pasture have been implicated (Cook 2003; Hernandez-Mendo et al. 2007; Keil et al. 2006; Loberg et al. 2004; Regula et al. 2004; Vokey et al. 2001), there are also indications that rates of lameness increase with increasing milk yield (European Commission, Scientific Committee on Animal Health and Animal Welfare (SCAHAW) 1999).

Over the past century, selective breeding has tripled the annual milk yield per cow to approximately 9,000 kg (USDA National Agricultural Statistics Service (NASS) 2009b), Since the 1980s, the dairy industry has succeeded in extracting an additional tonne of production per cow every 8 or 9 years (Lindhe and Philipsson 1998). The metabolic drain during the weeks of peak lactation has been considered comparable to the human equivalent of $6 \mathrm{~h}$ of jogging daily (Webster 1986).

The excessive metabolic burden placed upon dairy cows by modern breeding programs can lead to ketosis, from an excessive mobilization of fat stores to satisfy caloric demands, or milk fever, from an excessive mobilization of calcium (Goff 2006), which can lead to terminal recumbency and coma from hypocalcemia (Hunt and Blackwelder 2002). US cows can no longer acquire the energy necessary to sustain such high milk yields from forage alone, so the diets of lactating cows now consist of 30-60\% feed concentrates, such as grain and slaughter waste (Eastridge 2006). Organic acid fermentation byproducts of feed concentrates can cause rumen acidosis (Goff 2006), which can disrupt rumen flora leading to endotoxemia-related laminitis (an inflammatory hoof disease) (Donovan et al. 2004), shock, or even death (Goff 2006; Owens et al. 1998).

In the US industry, cows produce an average of 729 days of milk before they are typically culled due to waning productivity (Tsuruta et al. 2005). The 2008 recall of 65 million $\mathrm{kg}$ of beef - the largest in US history - was the result of violations of bovine spongiform encephalopathy (BSE) regulatory controls at one such "spent" dairy cow slaughter plant (USDA 2008b). The diminished body condition of those nonambulatory "downer" cows can be tied to the unmitigated selection for high milk yields (Grandin 2001), as well as the departure from strict herbivory blamed for the emergence and spread of BSE in the first place (Bradley and Wilesmith 1993).

Mastitis (an inflammatory udder disease) is the second leading cause of mortality in the US dairy industry, responsible for $16.5 \%$ of recorded deaths (USDA 2008a). One-hundred percent of large dairy operations in Dairy 2007, the latest USDA national survey, report problems with mastitis (USDA 2008a). Selective breeding for productivity has been identified as a predisposing factor (Heringstad et al. 2003; 
Van Dorp et al. 1998), though the overcrowded (Barkema et al. 1999), unhygienic conditions (Schreiner and Ruegg 2003; Schukken et al. 1990) and the trauma caused by milking machines to teat tissues may also contribute (Sordillo 2005). The extent to which animal health indices such as udder condition and musculoskeletal fitness are factored into genetic selection goals remains strictly based on economic merits alone (Cunningham and Tauebert 2009).

\section{Porcine Stress Syndrome in Pigs}

The intensive breeding of pigs for heavier muscling has led to a susceptibility to porcine stress syndrome (Wendt et al. 2000), in which electric prodding and other stressors can trigger hypermetabolism, muscle rigidity, and acute death from malignant hyperthermia (Merck Veterinary Manual 2008). Postmortem, their muscles can become pale, soft, and exudative, which many consumers find objectionable, due to the denaturing of muscle proteins. Although the condition has cost the industry hundreds of millions of dollars a year (Mitchell and Heffron 1982), it has not yet been eliminated due in part to an overriding financial gain. Namely, the same mutation that leads to the disorder, a change in the gene coding for a skeletal muscle calcium channel, is the same genetic defect that adds $2-3 \%$ to the dressed carcass weight in muscle hypertrophy (MacLennan and Phillips 1992). A similar condition in turkeys has likewise been linked to the intensive selection for increased muscling (Strasburg and Chiang 2009).

Osteoporosis and Cloacal Prolapse in Egg-Laying Hens

Whereas ancestors to the modern-day chicken laid 10 to 15 eggs a year (Romanov and Weigend 2001), today's laying hens produce more than ten times that number (USDA NASS 2008a). An estimated 80-89\% of commercial egg-laying hens suffer from osteoporosis (Webster 2004) due to the excessive mobilization of skeletal calcium for egg shell formation (Riddell 1992). The resulting bone fractures now constitute a major cause of hen mortality (Weber et al. 2003). The collapse and infolding of the ribs caused by cracks at the sternal and vertebral junctions are most commonly seen in fatal cage-layer osteoposis (Mayeda and Ernst 2008).

A loss of muscular elasticity from excessive production (along with a consumer premium for "jumbo" eggs) places hens at risk for oviduct prolapse during egg-laying (Alberta Agriculture and Rural Development (AARD) 2002; Keshavarz 1990), which can lead to hemorrhage, infection, and cloacal cannibalism (AARD 2002; Newberry 2004). The steroidal sex hormone activity associated with heavy egg production may explain the common prevalence of both benign and malignant reproductive tract tumors, as well as predispose hens to $E$. coli salpingitis, which can fatally fill the body cavity with a caseous exudate (cheese-like ooze) (Barnes et al. 2003).

\section{Skeletal and Cardiovascular Disorders in Turkeys}

Farming interests have transformed Ben Franklin's tree-perching "Bird of Courage" into a flightless gargantua bred to grow so fast that today's commercially raised 
turkeys, Wise and Jennings (1972) concluded, "are on the verge of structural collapse." Wild turkeys grow to be less than $4 \mathrm{~kg}$ (Healy 1992), whereas the average turkey raised for meat is approximately $13 \mathrm{~kg}$ (USDA NASS 2007). Their skeletons are often unable to adequately support such weight, leading to valgusvarus angular ("knock-kneed") bone deformities (Smith 1991), degenerative hip joint disease (Duncan et al. 1991), and up to $20 \%$ mortality due to lameness in problem flocks. Turkeys with avulsed tendons may only be able to move by creeping on their hocks and may be unable to access food and water (Julian 1984a).

Turkeys have been bred for such heavy body weight that they are physically incapable of mating, necessitating artificial insemination via tube or syringe (Rauw et al. 1998). Breeding stock are kept alive longer than those raised exclusively for slaughter. Given the adverse consequences of accelerated growth, these breeding birds are severely feed restricted in order to survive to sexual maturity and maintain reproductive performance (Nestor et al. 1980). At termination of breeding, at least $75 \%$ of turkey breeders suffer from abnormal gait or lameness (Hocking 1992). Duncan et al. (1991) found that all male breeders had extensive hip joint degeneration, and behavioral assessments with and without anti-inflammatory steroid injections strongly suggest that turkeys experience chronic pain from these hip problems.

The growth of commercial strains may outpace cardiovascular capacity in addition to skeletal integrity (Frank et al. 1990; Mutalib and Hanson 1990). Sudden death associated with acute heart failure and perirenal hemorrhage (bleeding around the kidneys) is a significant cause of mortality for rapidly growing turkey toms, regarded by some in industry as sign of "good flock health and fast growth rate as in the case of sudden death syndrome (flip-over) in broiler chickens" (Mutalib and Hanson 1990).

\section{Skeletal and Cardiovascular Disorders in Broiler Chickens}

"Broilers," commercial breeds of chickens raised for meat, arguably suffer the greatest welfare detriment from extant breeding technologies. Compared to 1925, broiler chickens now grow more than twice as large in less than half the time, reaching slaughter weight in less than 7 weeks (Aho 2002; National Chicken Council 2008). To put their growth rate into perspective, the University of Arkansas Cooperative Extension (2006) calculates: "If you grew as fast as a chicken, you'd weigh $349 \mathrm{lb}$ at age 2."

In the United States, approximately 50 million layers (USDA NASS 2009a) are used to breed approximately 9 billion broilers annually (USDA NASS 2009c). Sharing the same genetic predisposition for accelerated growth, fewer than half of these broiler breeders would survive more than one year if fed ad libitum (Katanbaf et al. 1989). In many parts of the world, including the United States, broiler breeders may therefore be fed on a "skip-a-day" regimen in which the animals are fed every other day (Coon 2002; Hocking 2004; Mench 1993; Shane 2007)—though this practice has been outlawed in several European countries (Hocking 2004).

Feed restriction causes stress (Mench 1991), behavior patterns characteristic of chronic hunger, undernourishment, specific nutritional deficiency, and frustration 
(Savory and Maros 1993). Indeed, research has found that feed-restricted birds' motivation to eat appear as high after meals as before them (Savory et al. 1993), indicating that breeding birds are rarely satiated. As a result, broiler breeders demonstrate other stress-induced stereotypic behavior such as repetitive pecking and pacing (Kjaer and Mench 2003).

Kept alive ten-times longer than their offspring, broiler breeders are vulnerable to a higher incidence of musculoskeletal disorders, even though they may be given as little as one-quarter of the amount of food they would eat ad libitum and weigh only half as much (Kjaer and Mench 2003; Savory et al. 1993). Duff and Hocking (1986) found that $92 \%$ of male broiler breeders had pelvic limb lesions, $85 \%$ had total or partial rupture of ligaments or tendons, $54 \%$ had total ligament or tendon failure at one or more skeletal sites, and $16 \%$ had total detachment of the femoral head.

Due to the metabolic demands imposed by fast growth selection, heart failure is a leading cause of death among their juvenile offspring (Boersma 2001), characterized by ascites (fluid build-up) and an enlarged flaccid heart (Balog 2003). Between 900,000 and 360 million chickens in the United States every year succumb to sudden death or "flip-over" syndrome, so named because the birds are often found on their backs after dying in a fit of convulsions and wing-beating (Julian 2004). Sudden death syndrome is a form of acute cardiovascular collapse now common in broiler chickens (Olkowski and Classen 1997) and has been linked to their rapid growth rate (Greenlees et al. 1989). Soledad Urrutia (1997), the editor of Avicultura Profesional, stated, "Mathematically, it is evident that the present rate of improvement in growth cannot be continued for more than a couple of decades, or the industry will be faced with a bird that virtually explodes upon hatching."

As body weight accumulates, the inbred predisposition to musculoskeletal deformities can lead to ruptured tendons or spontaneous fracture (Julian 2004, 1984b). During the finishing period, locomotor activity in fast-growing breeds has been found to be dramatically reduced compared to slow-growing heritage breeds (Bizeray et al. 2000). Combined with poor litter condition, the relative immobility of the birds leads to increased incidence of painful contact dermatitis, such as breast blisters and hock burns from the ammonia released from their decomposing waste (Estevez 2002). Birds crippled with severe twisted leg deformities or tibial dyschondroplasia (abnormal cartilage growth) may be forced to use their wing tips as crutches or crawl on their shanks to access food and water (Butterworth 1999).

As a direct result of selective breeding for accelerated muscle growth (Whitehead et al. 2003), studies consistently show that approximately 25-30\% of broiler chickens suffer from have gait defects severe enough to significantly impair walking ability (Bagshaw et al. 2006; Kestin et al. 1992; Knowles et al. 2008; Sanotra et al. 2001), and additional research strongly suggests that birds at this level of lameness are in pain (Danbury et al. 2000; McGeown et al. 1999). This translates into approximately 2.5 billion animals in the United States alone every year suffering from chronic pain due to industry breeding priorities that emphasize economic fitness at the expense of physical fitness (Whitehead et al. 2003). "This must constitute," Webster (1995) concludes, "in both magnitude and severity, the single most severe, systematic example of man's inhumanity to another sentient animal."

Tabler and Mendenhall (2003), however, offer the following economic analysis: 
"Two decades ago the goal of every grower was to ensure that the flock grew as rapidly as possible. However, the industry has developed a broiler that, if grown as rapidly as possible, will achieve a body mass that cannot be supported by the bird's heart, respiratory system or skeleton.

The situation has forced growers to make a choice. Is it more profitable to grow the biggest bird possible and have increased mortality due to heart attacks, ascites, and leg problems or should birds be grown slower so that birds are smaller, but have fewer heart, lung and skeletal problems?... A large portion of growers' pay is based on the pound of salable meat produced, so simple calculations suggest that it is better to get the weight and ignore the mortality."

\section{Population Health Concerns Raised by Transgenesis}

Grahame Bulfield, then-director of the Roslin Institute where the cloned sheep Dolly was created, is quoted as saying:

"The view I take on animal welfare is that the technology itself is a red herring. If an animal is lame because of genetic modification or selective breeding or poor nutrition, or because I kick it, it is wrong that it's lame. So you have to pay attention to the phenotype - that is, to the animal itselfrather than the technique that produces the problem" (Bulfield et al. 1998).

It is reasonable to assume that further selection for even greater production efficiency is likely to exacerbate welfare problems irrespective of the method used (Christiansen and Sandøe 2000), but the speed, power, and ecologically disruptive potential of genetic engineering are unique. Selective breeding is a potent tool, enabling humankind, for example, to turn Chinese wolves into poodles, but that was over a period of 14,000 years (Pennisi 2002). Dramatic changes can be induced by gene manipulation in a single generation, and few of the usual checks and balances imposed by natural selection may apply. In natural or artificial selection, the trait that is chosen comes coupled to a constellation of linked attributes that may, in many cases, help the animal maintain homeostatic balance. Due to the single-gene nature of transgenic change, however, engineered animals may suffer a greater loss of fitness than their selectively bred counterparts in conforming form to function. This has been demonstrated in transgenic fish and may have far-reaching consequences.

\section{Trojan Gene Effect}

Several species of GE fish reportedly stand ready to be marketed, pending government approval: transgenic tilapia in Cuba, transgenic carp in the People's Republic of China, and transgenic salmon in the United States and Canada (Kaiser 2005), the latter of which, the North American AquAdvantage ${ }^{\mathrm{TM}}$ salmon, is positioned to become the first transgenic animal available for human consumption. Like other animals in agriculture, farmed fish undergo genetic manipulation through selective breeding to enhance economically favored traits such as rapid growth rate 
(Aleström and de la Fuente 1999; Dunham and Devlin 1999) which may have deleterious welfare effects (Håstein 2004). Genetic selection for salmon size over a period of 10 years has been shown to increase average weights by more than $60 \%$ (Hershberger et al. 1990). Transgenic coho Salmon (Oncorhynchus kisutch) engineered with a growth hormone construct can be $1,100 \%$ heavier on average, though one specimen grew to be 37-times larger than non-transgenic controls (Devlin et al. 1994).

Although unexpected and sometimes severe phenotypic changes such as acromegaly-like cranial disfigurements have been noted in transgenic salmon, a larger concern surrounds their overall average fitness given numerous metabolic, morphologic, and allometric (size/weight relationship) differences (Kaiser 2005). Compared to wild-type salmon (O. kisutch), growth hormone construct salmon exhibit lower tolerance to low oxygen environments, presumably due to the physiological cost exacted by rapid growth (Sundt-Hansen et al. 2007). The critical swimming speed of salmon genetically engineered to grow twice as fast is approximately twice as slow as the speed of similarly sized non-transgenic controls (Farrell et al. 1997), potentially impairing the ability of GE salmon to forage and avoid predators. Similarly, non-transgenic catfish (Ictalurus punctatus) exhibit better predator-avoidance skills compared to growth hormone construct catfish (Dunham and Devlin 1999). The concern is that should such transgenic fish escape into the wild-a common occurrence in aquaculture (Goldburg et al. 2001) - they could lead to conspecific species population extinction (Muir and Howard 1999).

Male transgenic medaka fish (Oryzias latipes), for example, possess an overwhelming significant mating advantage compared to wild-type medaka males due to their larger body size. Should their offspring have reduced fitness, however, mathematical modeling suggests a "Trojan gene effect," where the combination of mating advantage with viability disadvantage could ultimately lead to the rapid collapse and extinction of both the transgenic and wild fish population in approximately 50 generations should transgenic males escape into the wild (Howard et al. 2004).

The National Academy of Sciences' report on animal biotechnology concluded that such potential environmental impacts present the greatest science-based concern (National Research Council of the National Academies (NRC) 2002). The class of species considered to pose the highest threat-fish-is the one closest to commercialization. The risk may be so great that biologic, rather than physical, containment of these animals may be necessary, such as induced sterility by triploidization (Wheeler et al. 2003).

\section{Using Biotechnology to Improve the Welfare of Farm Animals}

The Biotechnology Industry Organization claims that the genetic engineering of animals in agriculture offers "tremendous benefit to the animal by enhancing health, well-being and animal welfare" (Gottlieb and Wheeler 2008). Though biotechnology could be used to ameliorate production-related disease, if past performance is 
any predictor of future behavior, animal agribusiness will likely use transgenesis to further industry goals of production efficiency at the expense of welfare, as producers tend to ignore questions of animal pain and distress unless it impinges on profitability (Rollin 2009).

Beyond the historical trajectory of genetic selection and the emergence of production-related disease, it may be beneficial for a more accurate assessment to reflect upon the impacts of the most widespread, current use of biotechnology in animal agriculture: recombinant bovine somatotropin (BST) in the United States. BST injection increases milk yield, but may also increase the rates of mastitis, lameness, and poor body condition (Canadian Veterinary Medical Association 1998; SCAHAW 1999). The European Commission's Scientific Committee on Animal Health and Animal Welfare concluded that "BST is causing poor welfare which would not occur if it were not used. The conclusion that should be drawn is that avoidable actions that result in poor welfare, such as BST usage, should not be permitted" (SCAHAW 1999). Despite the welfare problems BST causes, however, millions of US dairy cows are repeatedly dosed throughout their lives, further illustration of industry priorities.

From the outset, production interests have explicitly been the first and foremost ambition of biotechnology in animal agriculture (Pinkert and Murray 1999). Starting with the Beltsville pigs in 1985, gene constructs designed to express growth factors constituted the largest class of transgenes initially experimentally transferred into livestock (Murray 1999). Biotechnology resources are unlikely to be diverted to relieve suffering for the same reason that existing breeding programs aren't generally employed to improve welfare; doing so, according to Kanis et al. (2005), may "result in less than maximal progress in economic traits."

\section{Improving Both Profitability and Welfare}

Unless government regulation or industry-wide voluntary compliance levels the playing field, economic competition will likely continue to drive breeding companies to focus on production-related traits. Should a conflict arise between production efficiency and welfare, the interests of the animals are unlikely to take precedence (Christiansen and Sandøe 2000). There are, however, uses of biotechnology from which producers and animals may both benefit.

Transgenic sex selection may be one such circumstance (Banner et al. 1995). For maximum productivity, the poultry industry segregates chicken breeds for meat and egg production. Broiler chickens are bred for rapid and excessive growth to maximize meat output, whereas egg-laying hens are bred for high rates of lay and to be small so that less feed being converted into eggs is spent on the upkeep of the rest of the animal (Arthur and Albers 2003). As a result of this selection, it is unprofitable to raise for meat the male offspring of egg-laying breeds. As unwanted by-products of the egg industry, male chicks are culled shortly after hatching. Engineering hens to lay only female chicks could double the yield for the breeding industry, while annually sparing hundreds of millions of chicks in the United States from death by maceration (mechanized grinding), gassing, slow suffocation, or dehydration (Fraser et al. 2001). Significant strides continue to be made in 
unraveling the genetics of chicken sex determination (Smith et al. 2009). Similarly, the creation of sires capable of only producing X-bearing sperm could prevent the births of the half million male calves considered of little or no value to the dairy industry (USDA 2006).

Tens of millions of piglets are castrated without anesthesia or postoperative analgesia every year in the United States to prevent "boar taint" of carcasses, a quality considered amenable to genetic manipulation (Pew Initiative on Food and Biotechnology (PIFB) 2005). No federal regulations protect animals while on the farm and standard agricultural practices such as castration and dehorning are typically exempt from state anti-cruelty statutes (Springsteen 2008).

Dehorning of beef cattle is another painful surgical procedure performed without anesthesia primarily to protect carcass quality (American Veterinary Medical Association 2007), but could be obviated by knocking out the single gene responsible for horn production (Rollin 1995). Polled (congenitally hornless) breeds already exist, which could make the transgenic creation of hornless cattle more palatable to the public. The carcass wastage due to bruising from horns is in part a result of the concentrated stocking density on feedlots. This raises the question: Is it preferable to engineer animals to fit industrial systems, or rather to engineer systems that imprimis fit the animals.

\section{Carving Square Pegs into Round Holes}

More than 95\% of egg-laying hens in the United States are confined in barren wire "battery cages" for 1-2 years before being culled, which may afford each hen less than a quarter of the space required to flap her wings unimpeded (United Egg Producers 2008). (Dawkins and Hardie 1989) According to Nobel laureate ethologist Konrad Lorenz (1980), "The worst torture to which a battery hen is exposed is the inability to retire somewhere for the laying act. For the person who knows something about animals it is truly heart-rending to watch how a chicken tries again and again to crawl beneath her fellow cagemates to search there in vain for cover." What if this nesting urge could be eliminated through genetic modification (PIFB 2005)? The infamous blind chicken experiments offer a parallel.

In 1985, Ali and Cheng published a series of experiments demonstrating that under conditions of intensive confinement, congenitally blind hens are more feedefficient than hens with sight. In a battery-cage setting, hens could peck each other to death, so the ends of their beaks are burned off as chicks to minimize injurious pecking damage (Duncan 2001). Blind hens do not appear to peck as much, though. Less feed energy spent on movement and less body heat loss from exposed skin due to feather loss could explain the improved feed conversion in blind compared to sighted hens. Further research was urged into the potential for incorporating this naturally occurring mutation into commercial lines of egg-laying hens raised inside battery cages (Ali and Cheng 1985). Transgenesis could speed this process.

The general public reportedly reacted negatively to the notion of deliberately breeding hens to be blind in order to save on feed costs (Lassen et al. 2006), but a larger issue remained largely unaddressed. The current paradigm requires animals be 
mutilated-whether via beak trimming, dehorning, detoeing, desnooding, disbudding, mulesing, comb removal, teat removal, teeth cutting, or tail docking- to fit the industrial production model. Rather than creating blind chickens better adapted to confinement, an informed public would likely outright reject confinement of birds in cages, as California voters did in 2008, passing a ballot initiative that phases out the use of battery cages. Winning by a 27-point spread, it was the most popular citizens' initiative in California state history (California 2008b). A 2007 American Farm Bureau survey found that a majority of Americans are in agreement that chickens should not be raised in battery cages (Norwood et al. 2007).

\section{Mike the Headless Chicken}

If demand for meat produced using least cost-production methods grows unabated, suggestions have been made for the design of decerebrate animals (Thompson 1997). Wyandotte rooster "Mike" (April 1945-March 1947) became a circus sideshow phenomenon after an incomplete decapitation left him with at least an intact brainstem. Reportedly he was able to walk and balance on a perch, and, fed with an eyedropper, lived 18 months with apparently no head (Guinness World Records 2005). This suggests one could engineer animals lacking higher brain function. Though perhaps aesthetically abhorrent, which is more troubling: designing anencephalic chickens or systems in which animals might have higher welfare brain dead than fully conscious?

Congenital analgia, as first described by Dearborn (1932), is a rare neurological disorder in which children are born unable to feel pain as a result of autosomal recessive loss-of-function mutations in part of a nerve sodium channel (Young 2008). Due to injury susceptibility, their longevity may be compromised (Drenth and Waxman 2007). Animals in agriculture, however, need only survive a fraction of their natural lifespan. The moral outrage such a breeding program could engender might be tempered as the public becomes increasingly aware of the current paradigm, in which billions of animals in agriculture suffer impaired welfare. Though differential tissue expression results in a lethal phenotype in knock-out rodent models (Ahmad et al. 2007), apparently no such studies on farm animal species have been published.

These scenarios speak to how far agribusiness has strayed from both traditional concepts of animal husbandry and from meeting societal expectations. This is acknowledged in the animal science textbook Contemporary Issues in Animal Agriculture:

"One of the best things modern animal agriculture has going for it is that most people...haven't a clue how animals are raised and 'processed.' In my opinion, if most urban meat eaters were to visit an industrial broiler house to see how the birds are raised...some, perhaps many, of them would swear off eating chicken and perhaps all meat. For modern animal agriculture, the less the consumer knows about what's happening before the meat hits the plate, the better" (Cheeke 2003). 


\section{Cultured Meat}

The pinnacle of production efficiency may not involve animals at all. Winston Churchill (1932) predicted: "Fifty years hence we shall escape the absurdity of growing a whole chicken in order to eat the breast or wing by growing these parts separately under a suitable medium." Though technical challenges remain, advances in skeletal muscle tissue engineering technology have improved the prospects of in vitro cultured meat production, and the genetic modification of farm animal muscle progenitor cells may accelerate commercial viability.

In a bioreactor perfused with a suitable culture medium, the proliferation of scaffolded embryonic myoblasts (immature muscle cells) or adult myogenic satellite cells cued for differentiation and myotube fusion can yield myofibers that can be harvested for processed meat products such as sausage, hamburger, or chicken nuggets (Edelman et al. 2005). Alternately, existing muscle tissue can be propagated ex vivo. Benjaminson et al. (2002) cultured skeletal muscle explants of goldfish (Carassius auratus), achieving a 79\% increase in explant surface area in one week's time. Inkjet printer-type technology layering cell mixtures onto gels is also being explored to create more complex three-dimensional tissue structures (Mironov et al. 2003).

The majority of cereal grains fed to animals in agriculture is currently lost to metabolism, as well as the formation of inedible structures such as the skeleton (Bender 1992). In light of global food insecurity and the growing vulnerability of food systems to climate change, among other concerns related to industrial meat production, cultured meat could become the most efficient way to satisfy nutritional and hedonic desires of meateaters (Datar and Betti 2010). A preliminary economic analysis presented at the 2008 In Vitro Meat Symposium suggests that carniculture can produce a product at a price competitive with meat (Vincent 2008). The genetic incorporation of an immortalizing telomerase into myogenic cell lines could extend the Hayflick limit of farm animal satellite cells such that the entire 270 million tonne annual global demand for meat could theoretically be met from a single parent cell (Edelman et al. 2005).

\section{Regulation of Genetically Engineered Animals in Agriculture}

Biotechnology has the potential to dramatically affect the welfare of farm animals on a massive scale, but whether this effect is positive or negative depends upon both its usage and its regulation. With one working day remaining in the Bush Administration, the FDA released its final Guidance for Industry, "Regulation of Genetically Engineered Animals Containing Heritable Recombinant DNA Constructs," applying the animal drugs provisions of the Federal Food, Drug, and Cosmetic Act (21 U.S.C. \$321 et seq.) to all GE animals (US Department of Health and Human Services, Food and Drug Administration Center for Veterinary Medicine (CVM) 2009b). Critics have condemned this decision for lacking adequate transparency and oversight (Mellon 2008). 
Regulators may restrict their scrutiny of transgenic applications only to changes substantially different from those derived from more traditional, already existing techniques. In the final risk assessment of farm animal cloning, the FDA discounted the "increased frequency of health risks" by arguing that they did not differ qualitatively from extant breeding technologies (CVM 2008). Just as state anticruelty to animals statutes typically exempt standard agricultural practices no matter how inflictive, such as castration without anesthesia or pain relief, evaluating biotechnology in only relativistic terms may further entrench and perpetuate practices with serious welfare repercussions.

Secondary effects may also be disregarded. The welfare issues associated with $\mathrm{BST}$, for example, are not directly attributable to the hormone itself, but rather to the intended consequence, the increase in milk production (Moore and Hutchinson 1992). US regulators reviewing BST may not have had the option of challenging the underlying complex of productivity-enhancing technologies and concluded that the detrimental effects were of no regulatory significance (Thompson 1997).

The FDA lacks the authority to address these broader ethical dimensions of farm animal transgenesis. According to the FDA (2009a), "the standard for approval [of genetically engineered animals] does not explicitly include ethics..." In general, US regulators are not authorized to make regulatory decisions on ethical grounds if no health or safety considerations exist (PIFB 2005), and, even when they do, they may be disregarded as in the case of agricultural animal cloning.

\section{Recommendations}

Though the FDA (CVM 2008) found "that animals involved in the cloning process (i.e., cattle and sheep surrogate dams, and clones) are at increased risk of adverse health outcomes," the agency gave farm animal cloning a favorable assessment. The European Food Safety Authority (EFSA) (2008) agreed that the "[r]educed welfare of clones can be assumed to occur as a consequence of adverse health outcomes," but admitted that the resultant ethical implications were outside their purview. The European Commission, the executive branch of the European Union, also referred the question to the European Group on Ethics in Science and New Technologies (EGE). The EGE is designed as a neutral, independent, pluralist, and multidisciplinary body composed of 15 experts appointed by the Commission that reports directly to the European Commission president. In contrast to the FDA and EFSA judgments, the EGE concluded: "Considering the current level of suffering and health problems of surrogate dams and animal clones...the EGE does not see convincing arguments to justify the production of food from clones and their offspring" (EGE 2008). In September 2008, the European Parliament voted 622 to 32 in favor of a proposal to ban cloning of animals for food (European Parliament 2008).

No advisory body exists in the United States to perform a role analogous to the EGE. Such a committee could evaluate both new and existing breeding programs for welfare problems and incorporate the expertise and perspectives of scientists and other stakeholders into the otherwise closed FDA animal drug licensing process. Creating an impartial forum, whether sponsored by a government body, private 
foundation, or professional association, incorporating active public participation to review safety information and provide input on all pending approval decisions could help clear the commercial pipeline for GE animal product acceptance (Christiansen and Sandøe 2000). The United Kingdom's Banner Commission or previous US presidential commissions offer models for such a forum (PIFB 2005).

Given the number of federal agencies with a stake in GE animal oversight, a new, more comprehensive regulatory regime may also be necessary. The White House could establish a task force to integrate agencies with the appropriate expertise and purview as was done in creating the Coordinated Framework for Biotechnology (51 Fed. Reg. 23302-23393 (June 26, 1986)). Orchestrated by the Office of Science and Technology Policy, the Coordinated Framework was successful in regulating biotechnology drugs and GE commodity crops to considerable commercial success-but neglected GE animals. Redirecting the framework to focus on GE animals could provide the coordination necessary to better address the environmental risks, but the assimilation of animal welfare interests may require a paradigmatic shift given the historic inadequacy of regulatory protections (Wilkins et al. 2005), as evidenced by a complete lack of statutory, regulatory, or administrative constraints on what can be done in pursuit of increasing agricultural animal prolificacy (Rollin, 2007).

In the Netherlands, a "no, unless" policy was enacted with the passage of the Animal Health and Welfare Act in 1992. All biotechnological activities with animals are prohibited unless officially exempted by the government after an independent committee of experts concluded specifically that there are no unacceptable animal welfare consequences (Brom and Schroten 1993). The Norwegian Animal Protection Act ( $\$$ ) goes beyond the Dutch policy, forbidding genetic alteration "by use of biotechnology or traditional breeding techniques if: a) this makes the animal poorly equipped to engage in normal behaviour or influences physiological functions negatively; b) the animal has to suffer unnecessarily [emphasis added]" (Kaiser 2005). Feister's (2008) Presumption of Restraint is stronger still, holding a default position of wariness that can only be overcome by compelling medical or veterinary reasons. She argues that the application of animal biotechnology merely for profit should be considered "frivolous" and unjustifiable. Similarly, a "Remediation Principle" has been proposed, making the case that only agricultural applications that improve the welfare of animals be pursued given the level of suffering already imposed by extant breeding technologies (Greger 2010), Kaiser (2005) argues that a precautionary approach is justified by our assumed ethical responsibility for the stewardship of animals in production, the traditional agriculture husbandry ethic that animals raised for human use should be afforded freedom to express basic natural behaviors and be protected from gratuitous suffering (Rollin 2004).

\section{Conclusion}

The National Academy of Sciences and National Research Council's Committee on Defining Science-Based Concerns Associated with Products of Animal 
Biotechnology expressed concern that "we already have pushed some farm animals to the limits of productivity that are possible by using selective breeding, and that further increases only will exacerbate the welfare problems that have arisen during selection" (NRC 2002). Given the emerging social ethic for farm animal welfare, as exemplified by the recent upsurge of husbandry standards (Miele and Bock 2007), ballot initiatives (Arizona 2006; California 2008a; Florida 2004; Ohio 2010), and state legislation (Colorado 2008; Maine 2009; Michigan 2009; Oregon 2007), using biotechnology to help mediate rather than exacerbate existing welfare problems could bring animal agriculture more in line with societal expectations, while improving consumer confidence in transgenic products.

Acknowledgments I would like to thank the anonymous reviewers for their helpful comments on a previous version of this paper.

Open Access This article is distributed under the terms of the Creative Commons Attribution Noncommercial License which permits any noncommercial use, distribution, and reproduction in any medium, provided the original author(s) and source are credited.

\section{References}

Ahmad, S., Dahllund, L., Eriksson, A. B., Hellgren, D., Karlsson, U., Lund, P. E., et al. (2007). A stop codon mutation in SCN9A causes lack of pain sensation. Human Molecular Genetics, 16(17), 21142121.

Aho, P. W. (2002). Introduction to the US chicken meat industry. In D. D. Bell \& W. D. Weaver Jr (Eds.), Commercial Chicken Meat and Egg Production, 5th Edition Norwell. MA: Kluwer Academic Publishers.

Alberta Agriculture Food and Rural Development. (2002). Common laying hen disorders: Prolapse in laying hens. http://www.agric.gov.ab.ca/livestock/poultry/prolapse.html. Accessed Jan 132010.

Aleström, P., \& de la Fuente, J. (1999). Genetically modified fish in aquaculture: Technical, environmental and management considerations. Biotecnologia Aplicada, 16(2), 127-130.

Ali, A., \& Cheng, K. M. (1985). Early egg production in genetically blind (rc/rc) chickens in comparison with sighted $(\mathrm{Rc}+/ \mathrm{rc})$ controls. Poultry Science, 64(5), 789-794.

American Veterinary Medical Association. (2007). Backgrounder: Welfare implications of the dehorning and disbudding of cattle. http://www.avma.org/reference/backgrounders/dehorning_cattle_bgnd.asp. Accessed Jan 132010 .

Arizona. (2006). Proposition 204. http://www.azsos.gov/results/2006/general/BM204.htm. Accessed Jan 132010.

Arthur, J. A., \& Albers, G. A. A. (2003). Industrial perspective on problems and issues associated with poultry breeding. In W. M. Muir \& S. E. Aggrey (Eds.), Poultry Genetics, Breeding and Biotechnology (pp. 1-12). Wallingford, UK: CABI Publishing.

Bagshaw, C. S., Matthews, L. R., \& Rogers, A. (2006). Key indicators of poultry welfare in New Zealand. Unpublished client report to MAF policy.

Balog, J. M. (2003). Ascites syndrome (pulmonary hypertension syndrome) in broiler chickens: Are we seeing the light at the end of the tunnel? Avian and Poultry Biology Reviews, 14(3), 99-126.

Banner, M., Bulfield, G., Clark, S., Gormally, L., Bignett, P., Kimbell, H., Milburn, C., \& Moffitt, J. (1995). Report of the Committee to consider the ethical implications of emerging technologies in the breeding of farm animals (London, UK: Her Majesty's Stationery Office). Ministry of Agriculture, Fisheries and Food.

Barkema, H. W., Schukken, Y. H., Lam, T. J. G. M., Beiboer, M. L., Benedictus, G., \& Brand, A. (1999). Management practices associated with the incidence rate of clinical mastitis. Journal of Dairy Science, 82(8), 1643-1654. 
Barnes, H. J., Vaillancourt, J. P., \& Gross, W. B. (2003). Colibacillosis. In Y. M. Saif, H. J. Barnes, A. M. Fadly, J. R. Glisson, L. R. McDougald, \& D. E. Swayne (Eds.), Diseases of Poultry, 11th Edition (pp. 631-652). Ames, IA: Iowa State Press.

Bender, A. (1992). Meat and meat products in human nutrition in developing countries. Food and Nutrition Paper 53. Food and Agriculture Organization of the United Nations, Rome, Italy. http://www.fao.org/docrep/t0562e/T0562E00.HTM. Accessed Jan 132010.

Benjaminson, M. A., Gilchriest, J. A., \& Lorenz, M. (2002). In vitro edible muscle protein production system (MPPS): Stage 1, fish. Acta Astronaut, 51, 879-889.

Bizeray, D., Leterrier, C., Constantin, P., Picard, M., \& Faure, J. M. (2000). Early locomotor behaviour in genetic stocks of chickens with different growth rates. Applied Animal Behaviour Science, 68(3), 231-242.

Boersma, S. (2001). Managing rapid growth rate in broilers. World Poultry, 17(8), 20-21.

Bradley, R., \& Wilesmith, J. W. (1993). Epidemiology and control of bovine spongiform encephalopathy (BSE). British Medical Bulletin, 49(4), 932-959.

Brom, F. W. A., \& Schroten, E. (1993). Ethical questions around animal biotechnology. The Dutch approach. Livestock Production Science, 36(1), 99-107.

Bulfield, G., Campbell, K., James, R., \& Wilmut, I. (1998). Voices from Roslin: the creators of Dolly discuss science, ethics, and social responsibility. Interview by Arlene Judith Klotzko. Cambridge Quarterly of Healthcare Ethics, 7(2), 121-140.

Butterworth, A. (1999). Infectious components of broiler lameness: a review. World's Poultry Science Journal, 55, 327-352.

California. (2008a). Proposition 2. http://www.sos.ca.gov/elections/sov/2008_general/maps/returns/pro ps/prop-2.htm. Accessed Jan 132010.

California. (2008b). Votes for and against November 4, 2008, state ballot measures. http://www. sos.ca.gov/elections/sov/2008_general/7_votes_for_against.pdf. Accessed Jan 132010.

Canadian Veterinary Medical Association. (1998). Report of the Canadian Veterinary Medical Association Expert Panel on rbST. Prepared for Health Canada, November. http://www.hc-sc.gc. ca/dhp-mps/vet/issues-enjeux/rbst-stbr/rep_cvma-rap_acdv_tc-tm-eng.php. Accessed Jan 132010.

Cheeke, P. R. (2003). Contemporary Issues in Animal Agriculture (3rd ed.). Upper Saddle River, NJ: Prentice Hall.

Christiansen, S. B., \& Sandøe, P. (2000). Bioethics: limits to the interference with life. Animal Reproduction Science, 60-61, 15-29.

Churchill, W. (1932). Fifty years hence. Thoughts and adventures (pp. 24-27). London, UK: Thornton Butterworth.

Colorado. (2008). Enrolled Senate Bill 08-201. http://www.leg.state.co.us/clics/clics2008a/csl.nsf/fsbill cont3/15738AC63DFF2DB1872573E600643253?open\&file=201_enr.pdf. Accessed Jan 132010.

Cook, N. B. (2003). Prevalence of lameness among dairy cattle in Wisconsin as a function of housing type and stall surface. Journal of the American Veterinary Medical Association, 223(9), 1324-1328.

Coon, C. N. (2002). Feeding broiler breeders. In D. D. Bell \& W. D. Weaver Jr (Eds.), Commercial Chicken Meat and Egg Production, 5th Edition Norwell. MA: Kluwer Academic Publishers.

Cunningham, E. P., \& Tauebert, H. J. (2009). Measuring the effect of change in selection indices. Dairy Science, 92(12), 6192-6196.

Danbury, T. C., Weeks, C. A., Chambers, J. P., Waterman-Pearson, A. E., \& Kestin, S. C. (2000). Selfselection of the analgesic drug carprofen by lame broiler chickens. The Veterinary Record, 146(11), 307-311.

Datar, I., \& Betti, M. (2010). Possibilities for an in vitro meat production system. Innovative Food Science and Emerging Technologies, 11, 13-22.

Dawkins, M. S., \& Hardie, S. (1989). Space needs of laying hens. British Poultry Science, 30(2), 413416.

Dearborn, G. V. N. (1932). A case of congenital general pure analgesia. The Journal of Nervous and Mental Disease, 75(6), 612-615.

Devlin, R. H., Yesaki, T. Y., Blagi, C. A., Donaldson, E. M., Swanson, P., \& Chan, W. K. (1994). Extraordinary salmon growth. Nature, 371(6494), 209-210.

Donovan, G. A., Risco, C. A., DeChant Temple, G. M., Tran, T. Q., \& van Horn, H. H. (2004). Influence of transition diets on occurrence of subclinical laminitis in Holstein dairy cows. Journal of Dairy Science, 87(1), 73-84.

Drenth, J. P. H., \& Waxman, S. G. (2007). Mutations in sodium-channel gene SCN9A cause a spectrum of human genetic pain disorders. The Journal of Clinical Investigation, 117(12), 3603-3609. 
Duff, S. R., \& Hocking, P. M. (1986). Chronic orthopaedic disease in adult male broiler breeding fowls. Research in Veterinary Science, 41(3), 340-348.

Duncan, I. J. H. (2001). Animal welfare issues in the poultry industry: Is there a lesson to be learned? Journal of Applied Animal Welfare Science, 4(3), 207-221.

Duncan, I. J. H., Beatty, E. R., Hocking, P. M., \& Duff, S. R. I. (1991). Assessment of pain associated with degenerative hip disorders in adult male turkeys. Research in Veterinary Science, 50(2), 200203.

Dunham, R. A., \& Devlin, R. H. (1999). Comparison of traditional breeding and transgenesis in farmed fish with implications for growth enhancement and fitness. In J. D. Murray, G. B. Anderson, A. M. Oberbauer, \& M. M. McGloughlin (Eds.), Transgenic Animals in Agriculture (pp. 209-229). Wallingford, UK: CABI Publishing.

Eastridge, M. L. (2006). Major advances in applied dairy cattle nutrition. Journal of Dairy Science, 89(4), $1311-1323$.

Edelman, P. D., McFarland, D. C., Mironov, V. A., \& Matheny, J. G. (2005). Commentary: In vitrocultured meat production. Tissue Engineering, 11(5-6), 659-662.

Espejo, L. A., Endres, M. I., \& Salfer, J. A. (2006). Prevalence of lameness in high-producing Holstein cows housed in freestall barns in Minnesota. Journal of Dairy Science, 89(8), 3052-3058.

Estevez, I. (2002). Poultry welfare issues. Poultry Digest Online, 3(2), 1-12.

European Commission Scientific Committee on Animal Health and Animal Welfare. (1999). Report on animal welfare aspects of the use of bovine somatotrophin. Adopted March 10. Brussels, Belgium. http://ec.europa.eu/food/fs/sc/scah/out21_en.pdf. Accessed Jan 132010.

European Food Safety Authority. (2008). Scientific opinion of the Scientific Committee. Food safety, animal health and welfare and environmental impact of animals derived from cloning by somatic cell nucleus transfer (SCNT) and their offspring and products obtained from those animals (Question No. EFSA-Q-2007-092). EFSA, Parma, Italy. The EFSA Journal, 767, 1-49. http://www.efsa.euro pa.eu/en/scdocs/doc/sc_op_ej767_animal_cloning_en.pdf. Accessed 13 January 2010.

European Group on Ethics in Science and New Technologies to the European Commission. (2008). Ethical aspects of animal cloning for food supply. Opinion No. 23, January 16. Brussels, Belgium. http://ec.europa.eu/european_group_ethics/activities/docs/opinion23_en.pdf. Accessed Jan 132010.

European Parliament (2008). MEPs call for ban on animal cloning for food. Press release issued September 3. Strasbourg, France. http://www.europarl.europa.eu/news/expert/infopress_page/03235965-245-09-36-904-20080902IPR35964-01-09-2008-2008-false/default_en.htm. Accessed Jan 13 2010.

Farrell, A. P., Bennett, W., \& Devlin, R. H. (1997). Growth-enhanced transgenic salmon can be inferior swimmers. Canadian Journal of Zoology, 75, 335-337.

Fiester, A. (2008). Justifying a presumption of restraint in animal biotechnology research. American Journal of Bioethics, 8(6), 36-44.

Florida. (2004). Constitution Article 10, Section 21. http://www.leg.state.fl.us/statutes/index.cfm?mode= constitution\&submenu=3\&tab=statutes\#A10S21. Accessed Jan 132010.

Frank, R. K., Newman, J. A., Noll, S. L., \& Ruth, G. R. (1990). The incidence of perirenal hemorrhage syndrome in six flocks of market turkey toms. Avian Diseases, 34(4), 824-832.

Fraser, D., Mench, J., \& Millman, S. (2001). Farm animals and their welfare in 2000. In D. J. Salem \& A. N. Rowan (Eds.), The state of the animals 2001 (p. 90). Washington, DC: Humane Society Press.

Goff, J. P. (2006). Major advances in our understanding of nutritional influences on bovine health. Journal of Dairy Science, 89(4), 1292-1301.

Goldburg, R. J., Elliott, M. S., Naylor, R. L. (2001). Marine aquaculture in the United States: Environmental impacts and policy options. Pew Oceans Commission, Arlington, VA. http://www. pewtrusts.org/uploadedFiles/wwwpewtrustsorg/Reports/Protecting_ocean_life/ env_pew_oceans_aquaculture.pdf. Accessed Jan 132010.

Gottlieb, S., \& Wheeler, M. B. (2008). Genetically engineered animals and public health: Compelling benefits for health care, nutrition, the environment, and animal welfare. Biotechnology Industry Organization, Washington, DC. http://www.bio.org/foodag/animals/ge_animal_benefits.pdf. Accessed Jan 132010.

Grandin, T. (2001). Welfare of cattle during slaughter and the prevention of nonambulatory (downer) cattle. Journal of the American Veterinary Medical Association, 219(10), 1377-1382.

Greenlees, K. J., Eyre, P., Lee, J. C., \& Larsen, C. T. (1989). Effect of age and growth rate on myocardial irritability in broiler chickens. Proceedings of the Society for Experimental Biology and Medicine, 190(3), 282-285. 
Greger, M. (2010). Trait selection and welfare of genetically engineered animals in agriculture. Journal of Animal Science, 88, 811-814.

Guinness World Records. (2005). Longest surviving headless chicken. http://web.archive.org/web/ 20051123021111/http:/www.guinnessworldrecords.com/content_pages/record.asp?recordid=54463. Accessed Jan 132010.

Håstein, T. (2004). Animal welfare issues relating to aquaculture. Proceedings of the Global Conference on Animal Welfare: an OIE initiative. World Organisation for Animal Health, Paris, France.

Healy, W. M. (1992). Behavior. In J. G. Dickson (Ed.), The Wild Turkey: Biology \& Management Mechanicsburg. PA: Stackpole Books.

Heringstad, B., Klemetsdal, G., \& Steine, T. (2003). Selection responses for clinical mastitis and protein yield in two Norwegian dairy cattle selection experiments. Journal of Dairy Science, 86(9), 29902999.

Hernandez-Mendo, O., von Keyserlingk, M. A., Veira, D. M., \& Weary, D. M. (2007). Effects of pasture on lameness in dairy cows. Journal of Dairy Science, 90(3), 1209-1214.

Hershberger, W. K., Myers, J. M., Iwamoto, R. N., McAuley, W. C., \& Saxton, A. M. (1990). Genetic changes in the growth of coho salmon (Oncorhynchus kisutch) in marine net-pens, produced by ten years of selection. Aquaculture, 85, 187-197.

Hocking, P. M. (1992). Musculo-skeletal disease in heavy breeding birds. In C. C. Whitehead (Ed.), Bone Biology and Skeletal Disorders in Poultry. Poultry Science Symposium No. 23 (pp. 297-309). Abingdon, UK: Carfax Publishing Co.

Hocking, P. M. (2004). Measuring and auditing the welfare of broiler breeders. In C. A. Weeks \& A. Butterworth (Eds.), Measuring and Auditing Broiler Welfare Wallingford. UK: CABI Publishing.

Howard, R. D., DeWoody, J. A., \& Muir, W. M. (2004). Transgenic male mating advantage provides opportunity for Trojan gene effect in a fish. Proceedings of the National Academy of Sciences of the United States of America, 101(9), 2934-2938.

Hunt, E., \& Blackwelder, J. T. (2002). Bovine parturient paresis (milk fever, hypocalcemia). In B. P. Smith (Ed.), Large Animal Internal Medicine (pp. 1248-1253). St. Louis, MO: Mosby.

Julian, R. J. (1984a). Tendon avulsion as a cause of lameness in turkeys. Avian Diseases, 28(1), $244-249$.

Julian, R. J. (1984b). Valgus-varus deformity of the intertarsal joint in broiler chickens. The Canadian Veterinary Journal, 25(6), 254-258.

Julian, R. J. (2004). Evaluating the impact of metabolic disorders on the welfare of broilers. In C. A. Weeks \& A. Butterworth (Eds.), Measuring and Auditing Broiler Welfare (pp. 51-59). Wallingford, UK: CABI Publishing.

Kaiser, M. (2005). Assessing ethics and animal welfare in animal biotechnology for farm production. Revue scientifique et technique (International Office of Epizootics), 24(1), 75-87.

Kanis, E., De Greef, K. H., Hiemstra, A., \& van Arendonk, J. A. M. (2005). Breeding for societally important traits in pigs. Journal of Animal Science, 83(4), 948-957.

Katanbaf, M. N., Dunnington, E. A., \& Siegel, P. B. (1989). Restricted feeding in early and latefeathering chickens. 1. Growth and physiological responses. Poultry Science, 68(3), 344-351.

Keil, N. M., Wiederkehr, T. U., Friedli, K., \& Wechsler, B. (2006). Effects of frequency and duration of outdoor exercise on the prevalence of hock lesions in tied Swiss dairy cows. Preventive Veterinary Medicine, 74(2-3), 142-153.

Keshavarz, K. (1990). Causes of prolapse in laying flocks. Poultry Digest, (September), 42.

Kestin, S. C., Knowles, T. G., Tinch, A. E., \& Gregory, N. G. (1992). Prevalence of leg weakness in broiler chickens and its relationship with genotype. The Veterinary Record, 131(9), 190-194.

Kjaer, J. B., \& Mench, J. A. (2003). Behaviour problems associated with selection for increased production. In W. M. Muir \& S. E. Aggrey (Eds.), Poultry Genetics, Breeding and Biotechnology (pp. 67-82). Wallingford, UK: CABI Publishing.

Knowles, T. G., Kestin, S. C., Haslam, S. M., Brown, S. N., Green, L. E., Butterworth, A., et al. (2008). Leg disorders in broiler chickens: prevalence, risk factors and prevention. PLoS ONE, 3(2), e1545.

Laible, G. (2009). Enhancing livestock through genetic engineering-recent advances and future prospects. Comparative Immunology, Microbiology and Infectious Diseases, 32(2), 123-137.

Lassen, J., Gjerris, M., \& Sandøe, P. (2006). After Dolly-ethical limits to the use of biotechnology on farm animals. Theriogenology, 65(5), 992-1004.

Lindhe, B., \& Philipsson, J. (1998). Conventional breeding programmes and genetic resistance to animal diseases. Revue Scientifique et Technique (International Office of Epizootics), 17(1), 291-301.

Lips, D., de Tavernier, J., Decuypere, E., \& van Outryve, J. (2001). Ethical objections to caesareans: Implications on the future of the Belgian White Blue. In M. Pasquali (Ed.), EurSafe 2001. Food 
Safety, Food Quality, and Food Ethics. Third Congress of the European Society for Agricultural and Food Ethics. Florence, Italy, October 3-5 (pp. 291-294). Milan, Italy: A\&Q.

Loberg, J., Telezhenko, E., Bergsten, C., \& Lidfors, L. (2004). Behaviour and claw health in tied dairy cows with varying access to exercise in an outdoor paddock. Applied Animal Behaviour Science, $89(1-2), 1-16$.

Lorenz, K. (1980). [Animals are sentient beings: Konrad Lorenz on instinct and modern factory farming] Devendran S, trans. Der Spiegel, 34(47), 251-264.

MacLennan, D. H., \& Phillips, M. S. (1992). Malignant hyperthermia. Science, 256(5058), 789-794.

Maine. (2009). Public Law, Chapter 127 LD 1021, item 1. http://www.mainelegislature.org/legis/bills/ bills_124th/chappdfs/PUBLIC127.pdf. Accessed Jan 132010.

Manual, Merck. Veterinary. (2008). Malignant hyperthermia: introduction (porcine stress syndrome). The Merck Veterinary Manual Whitehouse Station, NJ: Merck \& Co., Inc.

Mayeda, B., \& Ernst, R. A. (2008). Prevention of fatal cage-layer osteoporosis. Avian Diseases, 52(3), 544-545.

McConnel, C. S., Lombard, J. E., Wagner, B. A., \& Garry, F. B. (2008). Evaluation of factors associated with increased dairy cow mortality on United States dairy operations. Journal of Dairy Science, 91(4), 1423-1432.

McGeown, D., Danbury, T. C., Waterman-Pearson, A. E., \& Kestin, S. C. (1999). Effect of carprofen on lameness in broiler chickens. The Veterinary Record, 144(24), 668-671.

McPherron, A. C., Lawler, A. M., \& Lee, S. J. (1997). Regulation of skeletal muscle mass in mice by a new TGF-beta superfamily member. Nature, 387(6628), 83-90.

McPherron, A. C., \& Lee, S. J. (1997). Double muscling in cattle due to mutations in the myostatin gene. Proceedings of the National Academy of Sciences of the United States of America, 94(23), 1245712461.

Medeiros, E. F., Phelps, M. P., Fuentes, F. D., \& Bradley, T. M. (2009). Overexpression of follistatin in trout stimulates increased muscling. American Journal of Physiology. Regulatory, Integrative and Comparative Physiology, 297(1), R235-R242.

Mellon, M. (2008). Re: docket number FDA-2008-D-0394. Guidance for industry, regulation of genetically engineered animals containing heritable rRNA constructs. Union of Concerned Scientists, November 18, Cambridge, MA. http://www.regulations.gov/fdmspublic/ContentViewer? objectId=09000064807b0ac8\&disposition=attachment\&contentType=pdf. Accessed Jan 132010.

Mench, J. A. (1991). Research note: feed restriction in broiler breeders causes a persistent elevation in corticosterone secretion that is modulated by dietary tryptophan. Poultry Science, 70(12), 25472550 .

Mench, J. A. (1993). Problems associated with broiler breeder management. In C. J. Savory \& B. O. Hughes (Eds.), Proceedings of the Fourth European Symposium on Poultry Welfare, Edinburgh, September 18-21 (pp. 195-207). Potters Bar, UK: Universities Federation for Animal Welfare.

Michigan. (2009). Enrolled house bill 5127. http://www.legislature.mi.gov/documents/2009-2010/billen rolled/House/pdf/2009-hNB-5127.pdf. Accessed Jan 132010.

Miele, M., \& Bock, B. (2007). Editorial: Competing discourses of farm animal welfare and agri-food restructuring. International Journal of Sociology of Food and Agriculture, 15(3), 1-7.

Mironov, V., Boland, T., Trusk, T., Forgacs, G., \& Markwald, R. R. (2003). Organ printing: computeraided jet-based 3D tissue engineering. Trends in Biotechnology, 21(4), 157-161.

Mitchell, G., \& Heffron, J. J. A. (1982). Porcine stress syndromes. In C. O. Chichester, E. M. Mrak, \& G. F. Stewart (Eds.), Advances in Food Research, Volume 28 (pp. 167-230). New York, NY: Academic Press, Inc.

Moore, D. A., \& Hutchinson, L. J. (1992). BST and animal health. In M. C. Hallberg (Ed.), Bovine Somatotropin and Emerging Issues: An Assessment (pp. 99-142). Boulder, CO: Westview Press.

Muir, W. M., \& Howard, R. D. (1999). Possible ecological risks of transgenic organism release when transgenes affect mating success: Sexual selection and the Trojan gene hypothesis. Proceedings of the National Academy of Sciences of the United States of America, 96(24), 13853-13856.

Murray, J. D. (1999). Genetic modification of animals in the next century. Theriogenology, 51(1), 149159.

Mutalib, A. A., \& Hanson, J. A. (1990). Sudden death in turkeys with perirenal hemorrhage: Field and laboratory findings. The Canadian Veterinary Journal, 31(9), 637-642.

National Chicken Council. (2008). US broiler performance: 1925 to present. http://www.nationalchicken council.com/statistics/stat_detail.cfm?id=2. Accessed Jan 132010. 
National Research Council of the National Academies Committee on Defining Science-based Concerns Associated with Products of Animal Biotechnology, Committee on Agricultural Biotechnology, Board on Agriculture and Natural Resources, and Board on Life Sciences. (2002). Animal Biotechnology: Science-based Concerns. Washington, DC: The National Academies Press.

Nestor, K. E., Bacon, W. L., \& Renner, P. A. (1980). The influence of genetic changes in total egg production clutch length, broodiness, and body weight on ovarian follicular development in Turkeys. Poultry Science, 59(8), 1694-1699.

Newberry, R. C. (2004). Cannibalism. In G. C. Perry (Ed.), Welfare of the Laying Hen. Poultry Science Symposium Series Vol. 27 Wallingford. UK: CABI Publishing.

Norwood, F. B., Lusk, J. L., \& Prickett, R. W. (2007). Consumer preferences for farm animal welfare: Results of a nationwide telephone survey. Working paper, August 17. Oklahoma State University, Department of Agricultural Economics, Stillwater, OK. http://asp.okstate.edu/baileynorwood/ Bailey/Research/InitialReporttoAFB.pdf. Accessed Jan 132010.

Ohio. (2010). Proposed amendment to Article XIV, Section 2 of the Ohio consitution. https://hsus.salsalabs.com/o/17002/images/OH\%202010\%20language.pdf. Accessed May 7, 2010.

Olkowski, A. A., \& Classen, H. L. (1997). Malignant ventricular dysrhythmia in broiler chickens dying of sudden death syndrome. The Veterinary Record, 140(7), 177-179.

Oregon. (2007). Enrolled Senate Bill 694. http://www.leg.state.or.us/07reg/measpdf/sb0600.dir/sb0694. en.pdf. Accessed Jan 132010.

Owens, F. N., Secrist, D. S., Hill, W. J., \& Gill, D. R. (1998). Acidosis in cattle: A review. Journal of Animal Science, 76(1), 275-286.

Palmiter, R. D., Brinster, R. L., Hammer, R. E., Trumbauer, M. E., Rosenfeld, M. G., Birnberg, N. C., et al. (1982). Dramatic growth of mice that develop from eggs microinjected with metallothioneingrowth hormone fusion genes. Nature, 300, 611-615.

Palmiter, R. D., Norstedt, G., Gelinas, R. E., Hammer, R. E., \& Brinster, R. L. (1983). Metallothioneinhuman GH fusion genes stimulate growth of mice. Science, 222, 809-814.

Payne, J. M. (1972). Production disease. Journal of the Royal Agricultural Society of England, 133, 6986.

Pennisi, E. (2002). Canine evolution. A shaggy dog history. Science, 298(5598), 1540-1542.

Pew Initiative on Food, Biotechnology. (2005). Exploring the moral and ethical aspects of genetically engineered and cloned animals. Summary of a multi stakeholder workshop held on January 24-26. MD: Rockville.

Pinkert, C. A., \& Murray, J. D. (1999). Transgenic farm animals. In J. D. Murray, G. B. Anderson, A. M. Oberbauer, \& M. M. McGloughlin (Eds.), Transgenic Animals in Agriculture (pp. 1-18). Oxon, UK: CABI Publishing.

Rauw, W. M., Kanis, E., Noordhuizen-Stassen, E. N., \& Grommers, F. J. (1998). Undesirable side effects of selection for high production efficiency in farm animals: A review. Livestock Production Science, 56(1), 15-33.

Regula, G., Danuser, J., Spycher, B., \& Wechsler, B. (2004). Health and welfare of dairy cows in different husbandry systems in Switzerland. Preventive Veterinary Medicine, 66(1-4), 247-264.

Riddell, C. (1992). Non-infectious skeletal disorders of poultry: an overview. In C. C. Whitehead (Ed.), Bone biology and skeletal disorders in poultry. Poultry science symposium No. 23 (pp. 119-145). Oxfordshire, UK: Carfax Publishing Company.

Rodgers, B. D., \& Garikipati, D. K. (2008). Clinical, agricultural, and evolutionary biology of myostatin: A comparative review. Endocrine Reviews, 29(5), 513-534.

Rollin, B. E. (1995). The Frankenstein Syndrome: Ethical and Social Issues in the Genetic Engineering of Animals. Cambridge, UK: Cambridge University Press.

Rollin, B. E. (2004). Annual meeting keynote address: Animal agriculture and emerging social ethics for animals. Journal of Animal Science, 82(3), 955-964.

Rollin, B. E. (2007). Ethics and the genetic engineering of animals. Presented at Animals \& Bioengineering: A Consideration of Law, Ethics and Science. Durham, NC: Duke University School of Law.

Rollin, B. E. (2009). Veterinary ethics and production diseases. Animal Health Research Reviews, 10(2), $125-130$.

Romanov, M. N., \& Weigend, S. (2001). Analysis of genetic relationships between various populations of domestic and jungle fowl using microsatellite markers. Poultry Science, 80(8), 1057-1063. 
Sanotra, G. S., Lund, J. D., Ersboll, A. K., Petersen, J. S., \& Vestergaard, K. S. (2001). Monitoring leg problems in broilers: A survey of commercial broiler production in Denmark. World's Poultry Science Journal, 57(1), 55-69.

Savory, C. J., \& Maros, K. (1993). Influence of degree of food restriction, age and time of day on behaviour of broiler breeder chickens. Behavioural Processes, 29(3), 179-190.

Savory, C. J., Maros, K., \& Rutter, S. M. (1993). Assessment of hunger in growing broiler breeders in relation to a commercial restricted feeding programme. Animal Welfare, 2, 131-152.

Sawatari, E., Seki, R., Adachi, T., Hashimoto, H., Uji, S., Wakamatsu, Y., et al. (2010). Overexpression of the dominant-negative form of myostatin results in doubling of muscle-fiber number in transgenic medaka (Oryzias latipes). Comparative Biochemistry and Physiology. Part A, Molecular \& Integrative Physiology, 155(2), 183-189.

Schreiner, D. A., \& Ruegg, P. L. (2003). Relationship between udder and leg hygiene scores and subclinical mastitis. Journal of Dairy Science, 86(11), 3460-3465.

Schukken, Y. H., Grommers, F. J., Van de Geer, D., Erb, H. N., \& Brand, A. (1990). Risk factors for clinical mastitis in herds with a low bulk milk somatic cell count. 1. Data and risk factors for all cases. Journal of Dairy Science, 73(12), 3463-3471.

Shane, S. M. (2007). Progress in refining standards, audits. October: WATT Poultry USA.

Smith, R. (1991). Cutting edge poultry researchers doing what birds tell them to do. Feedstuffs, September 9.

Smith, C. A., Roeszler, K. N., Ohnesorg, T., Cummins, D. M., Farlie, P. G., Doran, T. J., et al. (2009). The avian Z-linked gene DMRT1 is required for male sex determination in the chicken. Nature, 461, 267-271.

Sordillo, L. M. (2005). Factors affecting mammary gland immunity and mastitis susceptibility. Livestock Production Science, 98(1-2), 89-99.

Springsteen, E. R (2008). States' animal cruelty statutes. National Agricultural Law Center, Fayetteville, AR. http://www.nationalaglawcenter.org/assets/animalcruelty/. Accessed Jan 132010.

Strasburg, G. M., \& Chiang, W. (2009). Pale, soft, exudative Turkey-The role of ryanodine receptor variation in meat quality. Poultry Science, 88(7), 1497-1505.

Sundt-Hansen, L., Sundström, L. F., Einum, S., Hindar, K., Fleming, I. A., \& Devlin, R. H. (2007). Genetically enhanced growth causes increased mortality in hypoxic environments. Biology Letters, $3(2), 165-168$.

Tabler, G. T., \& Mendenhall, A. M. (2003). Broiler nutrition, feed intake and grower economics. Avian Advice, 5, 8-10.

Thompson, P. B. (1997). Ethics and the genetic engineering of food animals. The Journal of Agricultural \& Environmental Ethics, 10(1), 1-23.

Thompson, P. B. (2008). Animal biotechnology: how not to presume. American Journal of Bioethics, $8(6), 49-50$.

Tsuruta, S., Misztal, I., \& Lawlor, T. J. (2005). Changing definition of productive life in US. Holsteins: effect on genetic correlations. Journal of Dairy Science, 88(3), 1156-1165.

University of Arkansas Cooperative Extension Service. (2006). Chickens-top 10 facts. http://web.archive. org/web/20060821123547/http:/www.kidsarus.org/kids_go4it/growit/raiseit/chickens.htm. Accessed Jan 132010.

Urrutia, S. (1997). Broilers for next decade: What hurdles must commercial broiler breeders overcome? World Poultry, 13, 28-30.

US Department of Health and Human Services, Food and Drug Administration CVM. (2008). Animal cloning: a risk assessment - final. Executive summary. Washington, DC. http://www.fda.gov/Animal Veterinary/SafetyHealth/AnimalCloning/ucm124762.htm. Accessed Jan 132010.

US Department of Health and Human Services, Food and Drug Administration CVM. (2009a). Genetically engineered animals. Consumer health information: Consumers Q\&A. http://www. fda.gov/AnimalVeterinary/DevelopmentApprovalProcess/GeneticEngineering/ GeneticallyEngineeredAnimals/ucm113605.htm. Accessed Jan 132010.

US Department of Health and Human Services, Food and Drug Administration CVM. (2009b). Guidance for industry. Regulation of genetically engineered animals containing heritable recombinant DNA constructs, final guidance, January 15. Washington, DC. http://www.fda.gov/downloads/Animal Veterinary/GuidanceComplianceEnforcement/GuidanceforIndustry/UCM052463.pdf. Accessed Jan 132010.

USDA. (2006). Veal from farm to table. http://www.fsis.usda.gov/Fact_Sheets/Veal_from_Farm_to_ Table/index.asp. Accessed Jan 132010. 
USDA NASS. (2007). Overview of the US Turkey industry. November 9. Washington, DC. http://usda.mannlib.cornell.edu/usda/current/usturk/usturk-11-09-2007.pdf. Accessed Jan 132010.

USDA. (2008a). Dairy 2007. Part I: Reference of dairy cattle health and management practices in the United States, 2007. USDA-APHIS-VS, CEAH. Fort Collins, CO \#N480.1007. http://www.aphis. usda.gov/vs/ceah/ncahs/nahms/dairy/dairy07/Dairy2007_Part_I.pdf. Accessed Jan 132010.

USDA. (2008b). Transcript of technical briefing regarding Hallmark/Westland Meat Packing Company two year product recall. February 17. Release No. 0047.08. http://www.usda.gov/wps/portal/!ut/ p/_s.7_0_A/7_0_1OB?contentidonly=true\&contentid=2008/02/0047.xml. Accessed Jan 132010.

USDA NASS. (2009a). Chickens and eggs 2008 summary. February. Washington, DC. http://usda.mannlib.cornell.edu/usda/current/ChickEgg/ChickEgg-02-26-2009.pdf. Accessed Jan 13 2010 .

USDA NASS. (2009b). Milk cows and production. http://www.nass.usda.gov/QuickStats/indexbysubject. jsp?Pass_group=Livestock\%20and\%20Animals. Accessed Jan 132010.

USDA NASS. (2009c). Poultry slaughter 2008 annual summary. February. Washington, DC. http://usda.mannlib.cornell.edu/usda/current/PoulSlauSu/PoulSlauSu-02-25-2009.pdf. Accessed Jan 132010.

United Egg Producers. (2008). United Egg Producers animal husbandry guidelines for US egg laying flocks, 2008 Edition, Alpharetta, GA. http://www.uepcertified.com/media/pdf/UEP-Animal-Wel fare-Guidelines.pdf. Accessed Jan 132010.

Uystepruyst, C., Coghe, J., Dorts, T., Harmegnies, N., Delsemme, M. H., Art, T., et al. (2002). Optimal timing of elective caesarean section in Belgian white and blue breed of cattle: the calf's point of view. The Veterinary Journal, 163(3), 267-282.

Van Dorp, T. E., Dekkers, J. C. M., Martin, S. W., \& Noordhuizen, J. P. T. M. (1998). Genetic parameters of health disorders, and relationships with 305-day milk yield and conformation traits of registered Holstein cows. Journal of Dairy Science, 81(8), 2264-2270.

Vincent, J. R. (2008). The in vitro meat consortium preliminary economics study. Project 29071. Version 5, March, Trondheim, Norway. http://invitromeat.org/images/Papers/invitro\%20meat\%20economics \%20study\%20v5\%20\%20march\%2008.pdf. Accessed Jan 132010.

Vokey, F. J., Guard, C. L., Erb, H. N., \& Galton, D. M. (2001). Effects of alley and stall surfaces on indices of claw and leg health in dairy cattle housed in a free-stall barn. Journal of Dairy Science, 84(12), 2686-2699.

Weaver, S. A., \& Morris, M. C. (2005). Risks associated with genetic modification: An annotated bibliography of peer reviewed natural science publications. Journal of Agricultural and Environmental Ethics, 18(2), 157-189.

Weber, R. M., Nogossek, M., Sander, I., Wandt, B., Neumann, U., \& Glünder, G. (2003). Investigations of laying hen health in enriched cages as compared to conventional cages and a floor pen system. Wiener Tierärztliche Monatsschrift, 90(10), 257-266.

Webster, J. (1986). Health and welfare of animals in modern husbandry systems-dairy cattle. In Practice, 8(3), 85-89.

Webster, J. (1995). Animal Welfare: A Cool Eye Towards Eden. Cambridge, M.A.: Blackwell Science.

Webster, A. B. (2004). Welfare implications of avian osteoporosis. Poultry Science, 83(2), 184-192.

Wendt, M., Bickhardt, K., Herzog, A., Fischer, A., Martens, H., \& Richter, T. (2000). Porcine stress syndrome and PSE meat: Clinical symptoms, pathogenesis, etiology and animal rights aspects. Berliner und Münchener Tierärztliche Wochenschrift, 113(5), 173-190.

Westhusin, M. (1997). From mighty mice to mighty cows. Nature Genetics, 17(1), 4-5.

Wheeler, M. B., Walters, E. M., \& Clark, S. G. (2003). Transgenic animals in biomedicine and agriculture: Outlook for the future. Animal Reproduction Science, 79(3-4), 265-289.

Whitehead, C. C., Fleming, R. H., Julian, R. J., \& Sørenson, P. (2003). Skeletal problems associated with selection for increased production. In W. M. Muir \& S. E. Aggrey (Eds.), Poultry Genetics, Breeding and Biotechnology (pp. 29-52). Wallingford, UK: CABI Publishing.

Wilkins, D. B., Houseman, C., Allan, R., Appleby, M. C., Peeling, D., \& Stevenson, P. (2005). Animal welfare: The role of non-governmental organisations. Revue Scientifique et Technique (International Office of Epizootics), 24(2), 625-638.

Wise, D. R., \& Jennings, A. R. (1972). Dyschondroplasia in domestic poultry. Veterinary Record, 91, 285-286.

Young, F. B. J. (2008). A life without pain? Hedonists take note. Clinical Genetics, 73(1), 31-33. 